\title{
Women Empowerment in Leading Environmental Education (EE) and Waste Management Advocacy (WMA) among Mothers in the Maritime University (JBLFMU-Molo) Philippines
}

\author{
Rolando A. Alimen, Emily R. Portal, Ma. Eddie A. Sia, Camila Jill R. Belandres, Elsie F. Gancia \\ College of Maritime Education, John B. Lacson Foundation Maritime University-Molo, Iloilo, Philippines \\ Email: ralimen@yahoo.com
}

How to cite this paper: Alimen, R. A., Portal, E. R., Sia, Ma. E. A., Belandres, C. J. R., \& Gancia, E. F. (2020). Women Empowerment in Leading Environmental Education (EE) and Waste Management Advocacy (WMA) among Mothers in the Maritime University (JBLFMU-Molo) Philippines. Open Journal of Social Sciences, 8 , 209-224.

https://doi.org/10.4236/jss.2020.812016

Received: September 7, 2020

Accepted: December 15, 2020

Published: December 18, 2020

Copyright $\odot 2020$ by author(s) and Scientific Research Publishing Inc. This work is licensed under the Creative Commons Attribution International License (CC BY 4.0).

http://creativecommons.org/licenses/by/4.0/

\begin{abstract}
The study determined women empowerment on environmental education (EE) and waste management advocacy (WMA) in the maritime university, Philippines. The researchers of this study employed a quantitative-qualitative research design. This study's respondents were the fifty-six (56) mothers of the students at JBLFMU-Molo, Iloilo City, Philippines. The results of this study revealed that as an entire group majority of the respondents have a "high" level of environmental education" and "high level of waste management advocacy." When classified according to status as mothers have a significant difference in environmental education (EE), the most dominant activities towards solid waste management are the following: reporting the abundance of trash in the community, recycling the unused things, doing compost, discussing with the Barangay officials the trash problem in the city, getting involved in the community to help improve the self-esteem of being a woman, and volunteering for religious reasons. The roles of the mothers leading towards women empowerment in environmental education (EE) and waste management advocacy (WMA) were categorized into three "themes," such as 1) educators and models, 2) advocators and initiators, and 3) helpers and collaborators.
\end{abstract}

\section{Keywords}

Women Empowerment, Waste Management Advocacy, Environmental Education 


\section{Introduction}

Studies conducted on the environment (Li, 2018; Chen, 2016) state that implementing environmental education in school systems becomes a primary issue of educators. Promoting practice should also be their main concern. The authors also found out that environmental education (EE) is influenced by environmental awareness and attitude.

Ali \& Sinhan (2013) mentioned that environmental degradation is a matter of great concern for humankind. Environmental activists and people, in general, aspire to foster a less polluted environment and promote the sustainable use of natural resources. They assume that environmental behavior change is a function of knowledge and awareness. Meanwhile, researchers claimed that women are considered important educators of children; therefore, they can stimulate change in behavior that can lead to conservation of food, water, energy consumption, and the protection of natural resources and biodiversity. In this study, environmental education (EE) needs environmental awareness and attitudes towards protecting Mother Earth as a life support base. Teachers should be the first initiators for generating environmental activism. Their human activities should be shaped to reduce environmental deterioration.

The study by Darusi \& Makokha (2018) mentioned that public participation requires that people be at the center of decision-making that concerns their lives. This is an essential feature of performance in establishing environmental policies. Funds should be used in the communities to enhance the living situation of the citizens. Participation and ownership of the locals in any project of the community should be appreciated properly. Public participation may be regarded as a way of empowerment and be a vital part of democratic governance. Concerning sustainability, public participation refers to an active process whereby beneficiaries influence the direction and execution of the environmental, developmental projects. It includes the empowering and development of the communities and marginalized people like children and women. This affects the capacity of the community to cope with change and adapt to new situations. The study underscored that projects that are worth sustaining today might not be so in the future.

\section{Statement of the Problem}

To understand the present study, the researchers advanced the following specific questions: 1) What is the level of environmental education (EE) of the women in this study as an entire group and classified according to different categories such as place of origin, type of occupation, and mother status? 2) What is the waste management advocacy (WMA) level as an entire group and classified according to different categories such as place of origin, type of occupation, and status of a mother? 3) Are there significant differences in environmental education (EE) of the women in this study when classified according to different categories such as place of origin, type of occupation, and 
mother status? 4) Are there significant differences in WMA when classified according to different categories such as place of origin, type of occupation, and mother status? 5) Is there a significant correlation between EE and WMA? 6) What are the most dominant solid waste management advocacies conducted by the locality respondents? 7) What are the most dominant environmental protection activities conducted by the respondents that contributed to conducting these activities? 8) What are the reasons for conducting environmental protection activities among the respondents? 9) What are the methods conducted by the respondents in response to waste management? 10) What are the contributing roles that empowered women towards environmental protection and waste management?

\section{Theoretical Framework of the Study}

The study is anchored on the "Empowerment Theory" by Ali \& Sinhan (2013), $\mathrm{Li}$, (2018), \& Chen (2016) that connects mental health to help those who struggle to create a responsive community. This theory deals with empowering women towards environmental concerns in the community. This process centered on the local community, involving mutual respect, critical reflection, caring group participation. People look for an equal share of valued resources and gain greater access and control. It also entails suggesting actions, activities, structures, and outcomes that result in empowerment. In this study, women were empowered to get involved in the community's advocacies to protect the environment; they speak and effect change in their respective places.

Empowerment theory also offers a model for understanding the process and the consequences of efforts to exert control and influence over decisions that affect one's life, organizational functioning, and community life quality. This theory also provides principles and a framework for organizing knowledge, suggesting ways to measure the construct in different settings, study the empowering process, and distinguish empowerment from other constructs such as self-esteem, self-efficacy, or locus of control. The empowerment theory's value is that people must acknowledge the different empowerment processes and their outcomes. This can help them gain control and obtain resources vital for decision making.

For this study, the empowerment theory applies to women in a framework of involvement and control over what they can do to preserve themselves and their environment. Their interpersonal and intrapersonal empowerment is at play in their advocacy of making their environment a better place to live in.

\section{Conceptual Framework of the Study}

The relationships of Environmental Education (EE), Waste Management Advocacy (WMA) among mothers in the Maritime University, and their categories such as place of origin, type of occupation, and mothers' status were reflected in Figure 1. The independent variable includes the respondent-related factors 


\section{INDEPENDENT VARIABLE}
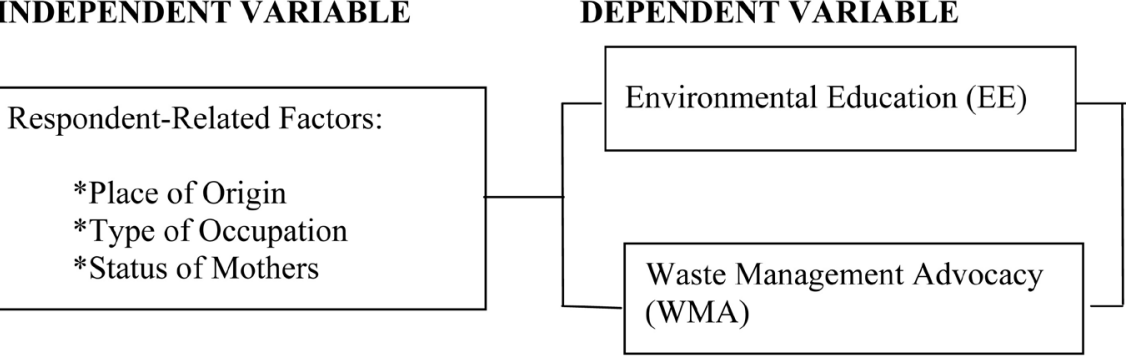

Figure 1. Environmental education (EE) and Waste management advocacy (WMA) among mothers in the maritime university as influenced by respondent-related factors.

comprising categories such as place of origin, type of occupation, and status of mothers. The dependent variable comprises environmental education (EE) and waste management advocacy (WMA).

\section{Related Studies and Literature}

According to Kumar \& Kumar (2013), empowerment is defined empowerment as giving a certain degree of autonomy and responsibility for making decisions regarding specific organizational goals. It means enriching people's jobs and giving authority to exercise control and taking responsibility for efforts' outcomes. To achieve empowerment, people must have the right mix of information, knowledge, power, and resources to work more exhaustively. The employees are empowered, their confidence degree, and self-reliance increase and create job satisfaction and high productivity. It is giving the team member the discretion or latitude over a certain task and other related activities. This study dealt that empowerment gives them the freedom to act and gives them a higher degree of responsibility and accountability. This includes a feedback system to identify the exact deviation and performance; employees can be empowered by assisting them in pursuing higher education.

Pavanello, Pozarny, \& de la O Campos (2015) mentioned that social protection policies and programs should be improved to enhance rural women's empowerment. The social protection scheme shall be strengthened about reducing gender inequalities and improving women's economic and social empowerment. In this study, empowerment referred to enhancing individuals' or groups' capacity to make choices and transform them into desired actions and outcomes. Women are economically empowered when they have both the ability and the power to make or act on the economic decision. According to Paredes-Chi \& Viga-de Alva (2017), environmental education was based on harmonic relationships with people and nature. In this study, the researchers stressed that students should promote and assume the care of Mother Earth and the environment. Darusi \& Makokha (2018) mentioned that people should understand the need to behave more responsibly towards nature. Nature protection engages mutual collaboration and support of the local, national, and international groups or individuals. This collaboration should include students and faculty to study the en- 
vironment and encourage behavioral change and actions, including a learning process that enhances knowledge and skills about the environment and its commitment to take responsible actions. Protecting the environment is so important that requirements and standards can be continuing towards environmental improvements that must be done regardless of cost. The current ecological crisis spreads freely on Earth and needs to establish firm and urgent measures for saving nature, preserving the human environment and ecosystem. There should be developmental models towards the wise use of resources for equity and durability. The youth and professionals should join forces to educate the public about natural environments' function and how human beings can manage their ecosystem. Environmental education deals with sustainable environment towards knowledge and awareness about environmental solutions, adaptation, and green behavior-development. This leads to developing students' intellectual, physical, moral, and social aspects with nature conservation and learning. Involvement and creativity with educational activities of the students would help improve the environmental-domain and ensure sustainability.

\section{Respondents of the Study}

The study respondents were the fifty-six (56) mothers of the senior high school students of Grade 10 of JBLFMU-Molo, Iloilo City for the School Year 2019-2019 who responded to become the respondents of the study for SY 2018-2019. They were classified according to the type of occupation and status of mothers. The distribution of the respondents is reflected in Table 1.

\section{Research Instrument}

The researchers designed the research instrument to address the objectives of the study. This instrument was composed of quantitative-qualitative items and questions regarding women's environmental preservation, conservation, and

Table 1. Distribution of the respondents.

\begin{tabular}{lcc}
\hline \multicolumn{1}{c}{ Category } & $\mathrm{f}$ & $\%$ \\
\hline $\begin{array}{l}\text { A. Entire Group } \\
\text { B. Type of Location }\end{array}$ & 56 & 100 \\
$\quad$ Rural & 30 & 54 \\
$\quad$ Urban & 26 & 46 \\
C. Type of Occupation of Mother & & 59 \\
Non-employed/Housekeeping & 33 & \\
Employed (Teacher, Government Employee, \& Others) & & 41 \\
Others & 23 & \\
D. Status as a Mother & & 71 \\
Mother with Husband & 40 & 29 \\
Single-Mother & 16 & \\
\hline
\end{tabular}


education. The researchers submitted the research-instrument to the experts in quantitative-qualitative research, Members of the Research Committee of the JBLFMU-Molo, and environmentalists for review and validation. All the comments, suggestions, and remarks of the jurors and validators' remarks were followed in the final revision of the research-instrument. After the validation of the experts, the researchers distributed it to the selected mothers for pilot-testing. The respondents' final administration of instruments was then conducted, and the researchers collected, tallied, and processed the data using the quantitative-qualitative method. The interpretation of the processed data was through the use of SPSS.

\section{Quantitative-Qualitative Tools}

This study's quantitative tools were frequency count, percentage, standard deviation, and rank to show the respondents' distribution according to different categories or groups. The researchers used the respondents' narrative answers to determine women's role relative to environmental issues and concerns.

\section{Results and Discussion}

\section{Environmental Education of the Respondents}

The results in Table 2 indicate that majority of the respondents have a "high level of environmental education" as an entire group $(M=4.1347)$. As to the origin's place, respondents from rural and urban areas have a "high level of environmental education" ( $\mathrm{M}=4.0829 \& \mathrm{M}=4.1408)$. About the type of occupation, respondents who were doing housekeeping and employed have a "high level of environmental education" ( $M=4.0545 \& M=4.1887)$. Respondents with supporting husbands have "high environmental education" $(M=4.0282)$, while those who were single mothers have "very high environmental education" ( $M=$ 4.3131). Data are shown in Table 2.

Table 2. Level of environmental education of the respondents when classified according to place of origin, type of occupation, and classification.

\begin{tabular}{lccc}
\hline \multicolumn{1}{c}{ Category } & Mean & $\begin{array}{c}\text { Standard } \\
\text { Deviation }\end{array}$ & Description \\
\hline A. Entire Group & 4.1347 & 0.44231 & High (H) \\
& & & \\
$\begin{array}{l}\text { B. Place of Origin } \\
\quad \text { Rural }\end{array}$ & 4.0829 & 0.45295 & High (H) \\
$\quad$ Urban & 4.1408 & 0.43650 & High (H) \\
C. Type of Occupation & & & \\
$\quad$ Housekeeping & 4.0545 & 0.4812 & High (H) \\
$\quad$ Employed (Teacher, Government Employee, \& Others) & 4.1887 & 0.3756 & High (H) \\
D. Status of Mother & & & \\
$\quad$ With Supporting Husband & 4.0282 & 0.4572 & High (H) \\
$\quad$ Single Mother & 4.3131 & 0.3348 & Very High (VH)
\end{tabular}

Legend: $4.21-5.00$ Very High (VH) $3.41-4.20$ High (H) 2.61 - 3.40 Moderate (M) 1.80 - 2.60 Low (L) 1.00 - 1.79 Very Low (VL). 


\section{Waste Management Advocacy}

The results reveal that the respondents have a "high level of waste management advocacy" as an entire group $(\mathrm{M}=4.1777)$. About a place of origin, respondents from the rural area have a "high level of waste management advocacy" $(\mathrm{M}=4.1570)$. In contrast, respondents from the urban area have a "very high level of waste management advocacy" $(\mathrm{M}=4.2450)$. As to the type of occupation, respondents who were doing housekeeping have a "high level of waste management advocacy" and those employed as teachers, government employees, \& others $(M=4.1961)$. When grouped according to mothers' classification, respondents with supporting husbands have a "very high level of waste management advocacy" ( $M=4.2230)$. In contrast, single mothers have a "high level of waste management advocacy" $(\mathrm{M}=4.1350)$.

Data are reflected in Table 3.

Differences in Environmental Education (EE) when the Respondents were grouped According to Place of Origin, Type of Occupation, and Status

The t-test results in Table 4 indicate that the respondents who were classified according to status of mothers have significant difference in environmental education (EE) with $\underline{\mathrm{t}}(54)=-2.257, p<0.05$, while those who were grouped according to place of origin with $\underline{\mathrm{t}}(54)=-0.487, \underline{p}>0.05$ and type of occupation with $\underline{\mathrm{t}}(54)=-1.119, p>0.05$ have no significant differences. This means that the absence of husbands has influenced the mothers' contributing roles towards environmental education (EE) to preserve and conserve the natural resources of Mother Earth. The single mothers have higher environmental education compared with those with supporting husbands (mothers with supporting husbands have "high environmental education" with $M=4.0282$ while those who were single mothers have "very high environmental education" with $\mathrm{M}=4.3131$ ). Data are shown in Table 4.

Table 3. Level of waste management advocacy (WMA) of the respondents when classified according to place of origin, type of occupation, and classification.

\begin{tabular}{|c|c|c|c|}
\hline Category & Mean & $\begin{array}{l}\text { Standard } \\
\text { Deviation }\end{array}$ & Description \\
\hline A. Entire Group & 4.1777 & 0.5572 & $\operatorname{High}(\mathrm{H})$ \\
\hline \multicolumn{4}{|l|}{ B. Place of Origin } \\
\hline Rural & 4.1570 & 0.5574 & $\operatorname{High}(\mathrm{H})$ \\
\hline Urban & 4.2450 & 0.5642 & Very High(VH) \\
\hline \multicolumn{4}{|l|}{ C. Type of Occupation } \\
\hline Housekeeping & 4.1991 & 0.5622 & High $(\mathrm{H})$ \\
\hline Employed (Teacher, Government Employee, \& Others) & 4.1961 & 0.5624 & $\operatorname{High}(\mathrm{H})$ \\
\hline \multicolumn{4}{|l|}{ D. Status of Mother } \\
\hline With Supporting Husband & 4.2230 & 0.5766 & Very High(VH) \\
\hline Single Mother & 4.1350 & 0.5186 & High $(\mathrm{H})$ \\
\hline
\end{tabular}


Table 4. t-test results in environmental education (EE) when the respondents were grouped according to place of origin, type of occupation, and status.

\begin{tabular}{|c|c|c|c|c|c|}
\hline Category & $\mathrm{N}$ & Mean & $\mathrm{t}$ & df & Sig (2-tailed) \\
\hline \multicolumn{6}{|l|}{ A. Place of Origin } \\
\hline Rural & 30 & 4.0827 & -0.487 & 54 & 0.628 \\
\hline Urban & 26 & 4.1408 & & & \\
\hline \multicolumn{6}{|l|}{ B. Type of Occupation } \\
\hline Housekeeping & 33 & 4.0545 & -1.119 & 54 & 0.268 \\
\hline $\begin{array}{l}\text { Employed (Teacher, Government } \\
\text { Employee, \& Others) }\end{array}$ & 23 & 4.1887 & & & \\
\hline \multicolumn{6}{|l|}{ C. Status of Mother } \\
\hline With Supporting Husband & 40 & 4.0282 & -2.257 & 54 & ${ }^{*} 0.028$ \\
\hline Single Mother & 16 & 4.3131 & & & \\
\hline
\end{tabular}

Differences in Waste Management Advocacy (WMA) when the Respondents were grouped according to Place of Origin, Type of Occupation, and Classification

t-test results in Table 5 reveal no significant differences in their Waste Management Advocacy (WMA) when grouped as to the different categories as indicated by the following $\mathrm{t}$ values, $\underline{\mathrm{t}}(54)=-0.586, p>0.05, \underline{\mathrm{t}}(54)=0.020, p>0.05$, and $\underline{\mathrm{t}}(54)=0.530, p>0.05$ respectively. These results indicate that when it comes to waste management advocacy (WMA), whatever the categories of mothers are, their roles in enhancing their leadership and empowerment to become concerned citizens of their community to save Mother Earth remain the same.

Relationship between Environmental Education (EE) and Waste Management Advocacy (WMA) of the Respondents

Using the Pearson's $r$ correlation coefficient, the result reveals that there was a negative and no significant relationship between the Environmental Education (EE) and Waste Management Advocacy (WMA) as indicated by $\mathrm{r}=-0.052, p>$ 0.05 . This result means that according to the mothers, their activities in each area can be done or initiated individually without influencing each other. The mothers in this study had conducted their environmental education activities (EE) separately with waste management advocacy (WMA) to exhibit their expression and exercise of their role and empowerment as women.

Data are shown in Table 6.

\section{Different Solid Waste Management Activities}

The results in Table 7 reveal that the most dominant activities towards solid waste management are the following: reporting the abundance of trash in the community ( $49, \mathrm{R}=1)$, recycling waste materials $(46, \mathrm{R}=2.5)$, doing compost (46, $\mathrm{R}=2.5$ ), discussing with the barangay officials the trash problem in the city $(45, R=4)$, getting involved in the community to help improve the self-esteem 
Table 5. t-test results in waste management advocacy (WMA) when the respondents were grouped according to place of origin, type of occupation, and classification.

\begin{tabular}{lccccc}
\hline \multicolumn{1}{c}{ Category } & N & Mean & t & df & Sig (2-tailed) \\
\hline $\begin{array}{l}\text { A. Place of Origin } \\
\quad \text { Rural }\end{array}$ & 30 & 4.1570 & -0.586 & 54 & 0.560 \\
$\quad$ Urban & 26 & 4.2450 & & & \\
$\begin{array}{l}\text { B. Type of Occupation } \\
\quad \text { Housekeeping }\end{array}$ & 33 & 4.1991 & 0.020 & 54 & 0.984 \\
$\quad \begin{array}{l}\text { Employed (Teacher, Government } \\
\text { Employee, \& Others) }\end{array}$ & 23 & 4.1960 & & & \\
$\begin{array}{l}\text { C. Status of Mother } \\
\quad \text { With Supporting Husband }\end{array}$ & 40 & 4.2230 & 0.530 & 54 & 0.598 \\
$\quad$ Single Mother & 16 & 4.1350 & & & \\
\hline
\end{tabular}
$p=0.05$.

Table 6. Correlation between environmental education (EE) and waste management advocacy (WMA).

\begin{tabular}{ccc}
\hline Category & & $\begin{array}{c}\text { Waste Management } \\
\text { Advocacy (WMA) }\end{array}$ \\
\hline Environmental Education (EE) & Pearson Correlation (r) & -0.052 \\
& Sig (2-tailed) & 0.704 \\
$\mathrm{~N}$ & 56 \\
\hline
\end{tabular}

Table 7. Different solid waste management activities of the respondents (Mothers).

\begin{tabular}{|c|c|c|c|}
\hline Different Solid Waste Management Activities & $\mathrm{f}$ & $\%$ & $\mathbf{R}$ \\
\hline Reporting the abundance of trash in the community & 49 & 87.5 & 1 \\
\hline Recycling the unused things & 46 & 82.1 & 2.5 \\
\hline Doing compost & 46 & 82.1 & 2.5 \\
\hline Discussing with the Barangay officials the trash problem in the city & 45 & 80.4 & 4 \\
\hline $\begin{array}{l}\text { Getting involved in the community to help improve the self-esteem of } \\
\text { being a woman }\end{array}$ & 44 & 78.6 & 5.5 \\
\hline Volunteering for religious reasons. Ex: Service for God & 44 & 78.6 & 5.5 \\
\hline Inform the Barangay official about the trash problem of the community & 43 & 76.8 & 7 \\
\hline Volunteering in environmental education to improve self-mood & 42 & 75 & 8.5 \\
\hline Have you noticed an improvement in the community since volunteering & 42 & 75 & 8.5 \\
\hline Talking to how to handle the trash problem in the community & 41 & 73.2 & 10 \\
\hline $\begin{array}{l}\text { Doing volunteering to improve relationships with the people in the } \\
\text { community }\end{array}$ & 39 & 69.6 & 11 \\
\hline Appreciating volunteer-work in the community & 37 & 66.1 & 13 \\
\hline $\begin{array}{l}\text { Requiring the children to be involved in volunteering on environmental \& } \\
\text { waste management activities }\end{array}$ & 36 & 64.3 & 14 \\
\hline Throwing the wastes properly in the dumpsite and prescribed dumping area & 28 & 50 & 15 \\
\hline Participating in a Coastal Cleanup activity & 22 & 39.3 & 16.5 \\
\hline Helping in the garbage collection of the city & 22 & 39.3 & 16.5 \\
\hline
\end{tabular}


of being a woman $(44, \mathrm{R}=5.5)$, and volunteering for religious reasons. Ex: Service for God $(44, \mathrm{R}=5.5)$.

Data are shown in Table 7.

Most dominant activities conducted by the respondents which contributed to environmental protection and reasons for conducting these activities are the following: "cleaning the household surrounding" and the reason is "helping the community to protect the Mother Earth," recycling of the plastics and the reason is "to help clean the environment," recycling of the plastics and the reason is "to help clean the environment" as indicated in Figure 2 and Figure 3.

Figure 4 shows the mothers' contributing roles to women empowerment in environmental education (EE) and waste management advocacy (WMA). These contributing roles are categorized into three "themes," which are:

1) Roles as educator and model. This means that the mothers have displayed their roles as educators by keeping them abreast with the new development in the environment, supported by the statement "help and suggest community and government activities which contributed to the welfare of the environment" from the participants. The model role played by the mothers was becoming leaders in protecting the environment as stated in this statement "as a mother you have to show and lead your children to practice cleanliness and plant trees in your surroundings."

2) Mothers played as Advocators and Initiators. These remarks support this result: "initiate to keep the cleanliness of the environment," "plant more trees," and "do something in our communities especially if it will give a benefit to our environment."

3) Helpers and collaborators are the other roles undertake by the mothers. These roles are in the vein with the following views by the participants, such as: "help each other to clean the environment," "as a mother I will help for my family from the waste disposal," and "I am willing to participate in activities and protect our mother earth because this is our home."

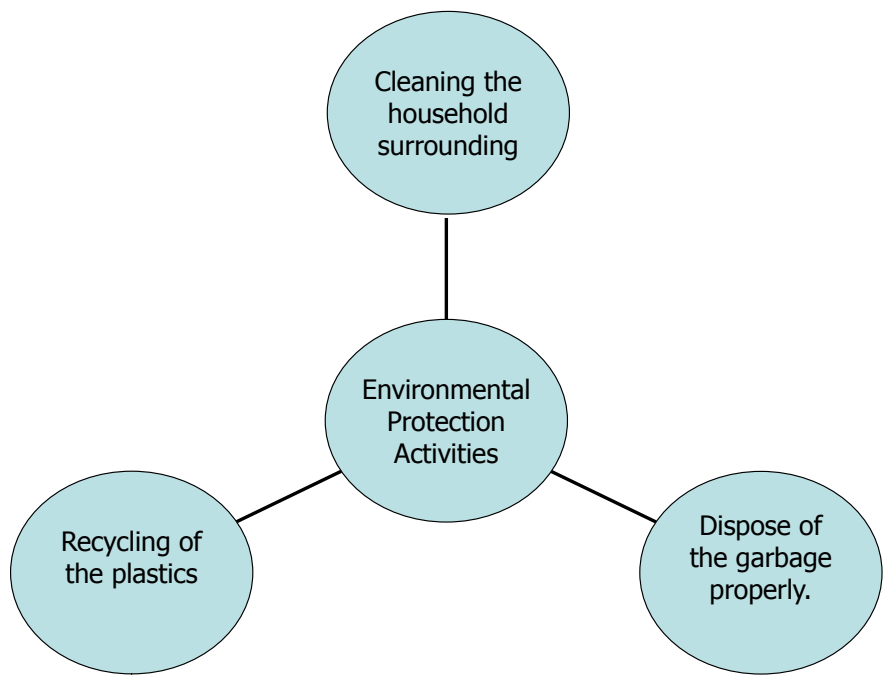

Figure 2. Environmental activities and reasons for doing such activities. 


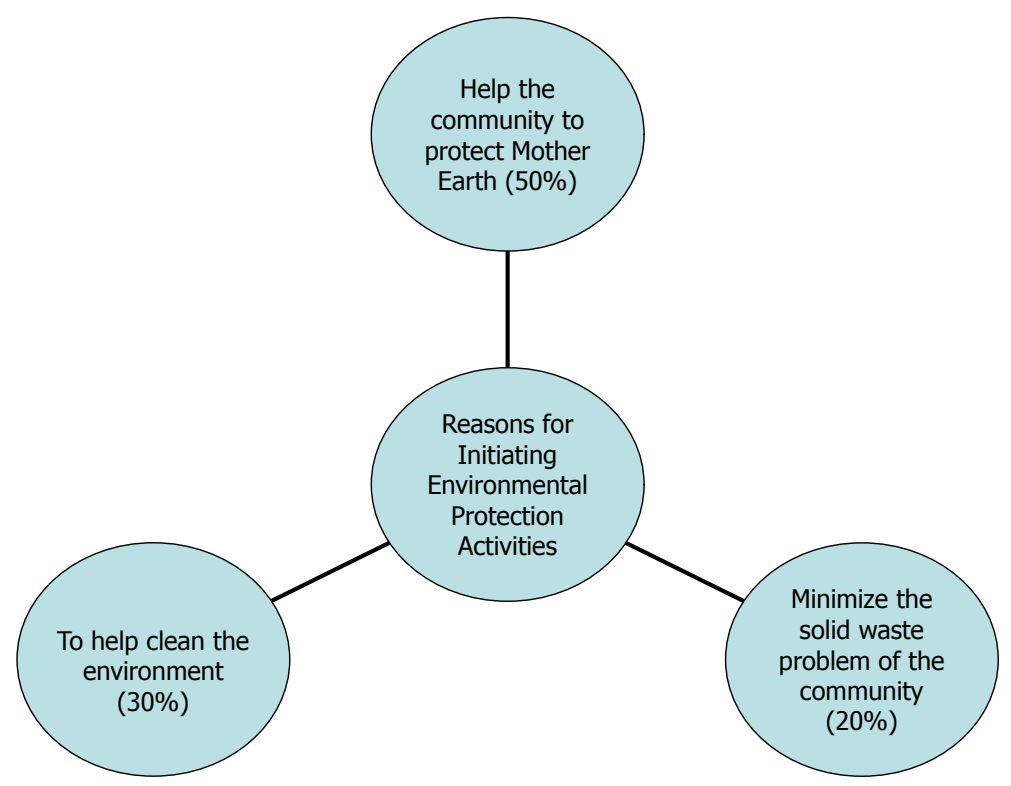

Figure 3. Reasons for initiating environmental activities.

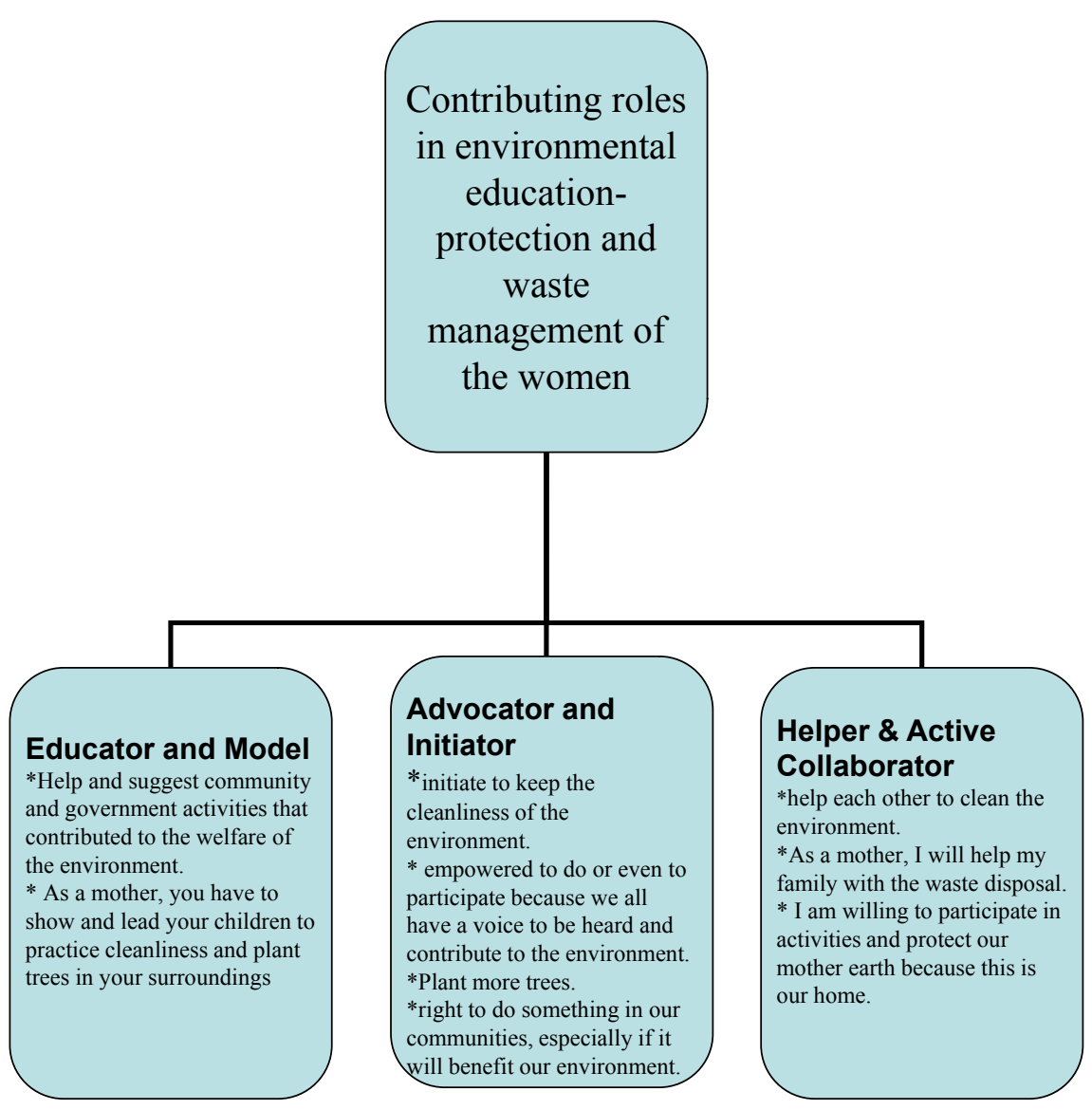

Figure 4. Contributing roles of mothers leading towards women empowerment.

\section{Conclusion}

Based on the findings of this study, the researchers conclude, such as the follow- 
ing:

The "high level of environmental education" and "high level of waste management advocacy" prove that the respondents imbibed the university's culture. These results were in the vein with studies conducted on the environment by Li (2018), \& Chen (2016), which state that a high level of environmental education and waste management could be attributed to environmental given by educators in their respective school systems. Besides, Ali \& Sinhan (2013) stressed that when environmental degradation is considered a "great concern of every individual," environmental education would become high. This high environmental education resulted in the protection of natural resources and biodiversity, and human activities should be shaped to reduce environmental deterioration.

High environmental education and waste management are connected to the study of Darusi \& Makokha (2018) that requires "people" as the center of decision-making. This is an essential feature of establishing environmental policies; participation and ownership of the locals in any community project should be appreciated properly. Public participation may be regarded as a way of empowerment and vital to concerned individuals.

The mothers in this study had conducted their environmental education activities (EE) separately with waste management advocacy (WMA) to exhibit their expression and exercise of their role and empowerment as women. This result shows that community participation is essential in managing environmental activities.

The most dominant activities towards solid waste management are the following: reporting the abundance of trash in the community, recycling the unused things, doing compost, discussing with the barangay officials the trash problem in the city, getting involved in the community to help improve the self-esteem of being a woman, and volunteering for religious reasons. The mothers' contributing roles lead towards women empowerment in environmental education (EE) and waste management advocacy (WMA). These contributing roles are categorized into three "themes," which are: 1) roles as educator and model, 2) advocators and initiators, and 3) helpers and collaborators. This result was anchored on Kumar \& Kumar (2013)'s study that "empowerment” is autonomy and responsibility for making decisions regarding specific organizational goals; it means enriching people's jobs and giving authority to exercise control and take responsibility for outcomes of efforts. To achieve empowerment, people must have the right mix of information, knowledge, power, and resources to work more exhaustively. Moreover, Pavanello, Pozarny, \& de la O Campos (2015) and Paredes-Chi \& Viga-de Alva (2017) believed that "empowerment" is the process of enhancing the capacity of individuals or groups to make choices and to transform those choices into desired actions and outcomes. Women are economically empowered when they have both the ability and the power to make or act on economic decisions. People should understand the need to behave more responsibly towards nature and nature protection engages mutual collaboration and support of the local, national, and international groups or in- 
dividuals. Environmental education deals with sustainable environment towards knowledge and awareness about environmental solutions, adaptation, and green behavior-development. This leads to developing students' intellectual, physical, moral, and social aspects concerning nature conservation and learning. Involvement and creativity with educational activities of the students would help improve the environmental-domain and ensure sustainability.

\section{Implications of the Present Study for Theory and Practice}

The present study results have led to certain theoretical and practical implications concerning empowering women leading to environmental issues and waste management. The results confirmed that "environmental education" becomes a primary issue for any individual, including mothers (Li, 2018; Chen, 2016).

In this study's results, the mothers/women were concerned with the environment and accepted that environmental degradation is a great concern. Environmental activists and people, in general, aspire to foster a less polluted environment and promote the sustainable use of natural resources. They assumed that environmental behavior change is a function of knowledge and awareness, as mentioned by Ali \& Sinhan (2013), Chen (2016), \& Cui et al. (2015).

The researchers claim that women are considered important educators of children; therefore, they can stimulate change in behavior that can lead to savings of food, water, energy consumption, and the protection of natural resources and biodiversity in this study.

In this study, environmental activities and initiatives shared by mothers engaged in environmental education (EE) for generating environmental awareness and practices towards protecting Mother Earth as a life support base. They should be the first initiators for generating environmental activism. Their human activities should be shaped to reduce environmental deterioration.

This study led to the practice that "public participation requires people to be at the center of decision-making" that concerns their lives. This is an essential feature of performance in establishing environmental policies. Participation and ownership of the locals, like mothers, in any community projects, should be checked and monitored properly. Public participation may be regarded as a way of empowerment among mothers and be a vital part of democratic governance, which leads to sustainability, public participation, active process-monitoring, and execution of the environmental, developmental activities and projects. It includes the empowering and development of the communities and marginalized people like children and mothers as respondents of this study as supported by the study of Darusi \& Makokha (2018).

This study affirmed that improving local welfare by training the people, specifically, mothers of this study, in local administrative duties and environmental management were very beneficial and had a significant impact to the community. This led to the theory that "empowerment" according to the study of Kumar \& Kumar (2013), is giving a certain degree of autonomy and responsibility 
for deciding on specific organizational goals; it means that enriching people's jobs and giving authority to exercise control and take responsibility for outcomes of efforts. To achieve empowerment, people must have the right mix of information, knowledge, power, and resources to work more exhaustively. The mothers in this study are empowered; their confidence degree and self-reliance increased and created satisfaction and high productivity levels. It is giving the mothers the discretion or latitude over certain tasks and other environmentally related activities. This study dealt with empowerment as giving individuals the freedom to act and giving them a higher degree of responsibility and accountability. This includes a feedback system to identify the exact deviation and performance. Individuals, especially the most marginalized people like mothers or women, can be empowered by assisting them in pursuing their environmental initiatives and advocacies.

The results led to a theory of "social protection policies and programs" to enhance the impact of "women empowerment," which leads to reducing gender inequalities and improving women's economic and social empowerment. In this study, empowerment asserted the "enhancing of individuals or groups' capacity," particularly mothers or women, to conduct activities and transform their environment into the desirable and environmentally friendly surrounding. Women or mothers are empowered when they have both the ability and the power to make or act on certain activities and make decision-making as posited by Pavanello, Pozarny, \& de la O Campos (2015).

This impacted the theory that "environmental education," according to $\mathrm{Pa}$ redes-Chi \& Viga-de Alva (2017), was based on harmonic relationships with the people and nature. Individuals should promote and assume the care of Mother Earth and the environment. The individuals should understand the need to behave more responsibly towards nature and nature protection engages mutual collaboration and support of the local, national, and international groups or individuals. Protecting the environment is so important that requirements and standards can be continuing towards environmental improvements that must be done regardless of cost. The current ecological crisis spreads freely on Earth and needs to establish firm and urgent measures for saving nature, preserving the human environment and ecosystem. There should be developmental models towards the wise use of resources for equity and durability. The youth and professionals should join forces to educate the public about natural environments' function and how human beings can manage their ecosystem. This study discovers that "environmental education" deals with sustainable environment towards knowledge and awareness about environmental solutions, adaptation, and green behavior-development, leading to the development of intellectual, physical, moral, and social aspects of students' nature conservation and learning. The mothers' or women's involvement and creativity with environmental-educational activities would improve the environmental-domain and ensure sustainability. 


\section{Recommendations}

After analyzing the results and conclusions of this study, the researchers would like to suggest the following:

1) Quantitative results and qualitative information, views, and inputs in this present study shall be given and discussed with CES (Community Extension Service) officers to have based-line data on empowerment concerning environmental education (EE) and waste management practices.

2) The results of the present study shall be discussed with the officers of environmental education (EE) and waste management or pollution control officer (PCO) of the school.

3) The officer-in-charge (OIC) of GAD shall look into the qualitative inputs and information to use these as a basis for initiating more specific programs towards women's empowerment in leading environmental protection and awareness.

4) The researchers suggest conducting a parallel study to determine other roles initiated by the women to empower them to conduct environmental initiatives and protection-awareness in their respective places.

\section{Conflicts of Interest}

The authors declare no conflicts of interest regarding the publication of this paper.

\section{References}

Ali, P., \& Sinhan, B. (2013). A Study of Environmental Awareness and Ecological Behavior among Female Bachelor of Education Students. Department of Education. S.S. Jalan Girls College, University of Calcutta, India. International Multidisciplinary Refereed E-Journal, 20.

Chen, M. F. (2016). Impact of Fear Appeals on Pro-Environmental Behavior and Crucial Determinants. International Journal of Adversity, 35, 74-92. https://doi.org/10.1080/02650487.2015.1101908

Cui, J. et al. (2015). The Influence of Christian Religiosity on a Managerial Decision Concerning the Environment. Journal of Business Ethics, 132, 203-231. https://doi.org/10.1007/s10551-014-2306-5

Darusi, D. M., \& Makokha, E. N. (2018). Determinants of Public Participation on Sustainability of County Government Project in Uasin Gishu County. International Journal of Recent Research in Social Sciences and Humanities (IJRRSSH), 5, 285-293.

Kumar, P. \& Kumar, A. (2013). Team Member Empowerment-An Empirical Study. Global Journal of Management and Business Research: A Administration and Management, 17.

Li, C. (2018). The Study of Environmental Education's Effect on Environmental Awareness and Environmental Attitude Is Based on Environmental Protection Law by the People Republic of China. Eurasia Journal of Mathematics, Science and Technology Education, 14, 2277-2285. https://doi.org/10.29333/ejmste/86214

Paredes-Chi, A. A., \& Viga-de Alva, M. D. (2017). Environmental Education Policy and Content of Contemporary Mexican National Curriculum for Primary Schools. Envi- 
ronmental Education Research, 24, 564-580.

Pavanello, S., Pozarny, P., \& de la O Campos, A. (2015). Qualitative Research on Women's Economic Empowerment and Social Protection-A Research Guide. Food and Agriculture Organization of the United Nations (FA).

https://www.fao.org/3/a-14420.e.pdf/www.fao.org/economic/ptop 